\title{
HOMOT JA HETEROT SUOMI24:SSÄ: ANALYYSI DIGITAALISISTA DISKURSSEISTA
}

\author{
Jarmo Harri Jantunen, kieli- ja viestintätieteiden laitos, \\ Jyväskylän yliopisto
}

\begin{abstract}
Artikkelissani tarkastelen Suomi24-keskustelupalstan homouteen ja heterouteen liittyviä toistuvia diskursseja. Analyysi on toteutettu korpusavusteisena diskurssintutkimuksena (CADS), jossa suureen dataan perustuva tilastollinen avainsana-analyysi nostaa esiin suomalaisella keskustelupalstalla sosiaalisesti jaettuja diskursseja. Tulokset yhtäältä tukevat aiempia media-analyyseissä tehtyjä havaintoja voimakkaista affekteista ja vihapuheesta sekä homoseksuaalisuuden käsittelyn politisoitumisesta ja uskonnollistumisesta. Toisaalta tutkimus myös paljastaa homodiskurssien henkilöitymisen tai liittymisen tiettyihin henkilöryhmiin ja paikkoihin. Heterodiskurssit puolestaan eroavat selvästi homodiskursseista: niille on tyypillistä sekä rationaalinen että tunnepohjainen suuntautumiseen, seksuaalisuuteen ja sukupuoleen liittyvä keskustelu ja omien halujen ja seksuaalisuuden itserepresentointi.
\end{abstract}

Avainsanat: diskurssi, fraseologia, heteroseksuaalisuus, homoseksuaalisuus, keskustelupalstat, sosiaalinen media

\section{SOSIAALINEN MEDIA JA SEKSUAALIVÄHEMMISTÖT}

Tutkimuksessani tarkastelen, millaisia diskursseja eli jaettuja sosiaalisia merkityksiä liittyy homoista ja heteroista ${ }^{1}$ puhumiseen Suomen suurimmalla keskustelupalstalla, Suomi24:ssä. Keskustelupalstan teksteistä on muodostettu opetus- ja tutkimuskäyt-

\footnotetext{
Kirjoittajan yhteystiedot:

Jarmo Harri Jantunen

Kieli- ja viestintätieteiden laitos, suomen kieli PL 35

40014 Jyväskylän yliopisto

jarmo.jantunen@jyu.fi
}

töön korpus, jonka sisältämien kansalaiskeskustelujen avulla voidaan tutkia muun muassa yhteiskunnallisten ilmiöiden syntyä, muutosta ja niistä käytävää keskustelua (Lagus, Pantzar, Ruckenstein \& Ylisiurua, 2016, s. 5, 40-42).

Sosiaalisen median keskusteluryhmistä on tullut yhä suositumpia mielipiteen ilmaisu-

\footnotetext{
1 Artikkelissa keskitytään seksuaalisista vähemmistöryhmistä vain homoihin eikä esimerkiksi lesboja ole tässä tutkimuksessa eroteltu omaksi ryhmäkseen. Lisäksi tutkimus on rajattu vain sanoihin homo ja hetero. Nämä rajaukset on tehty, koska homo ja hetero ovat yleisempiä kuin homoseksuaali ja heteroseksuaali (tarkemmin luvussa SuOMi24AINEISTO JA AVAINSANAT) ja koska useiden ilmausten yhtäaikainen aineistovetoinen merkitys- ja diskurssianalyysi vaatisi laajemman käsittelyn.
} 
kanavia ja tiedonhaun välineitä. Verkkokeskusteluille on tyypillistä, että niissä sisällön tuottajana on kuka tahansa, jolla on tarve tuoda asiansa julki eli luoda ja jakaa niin sanottua käyttäjäsisältöä (Kaplan \& Haenlein, 2010, s. 61; Marshal, 2006, s. 638; Matikainen, 2011, s. 94). Vaikka verkkokeskustelu luo mahdollisuuden käydä syvällistä ja asioita monelta kantilta valottavaa keskustelua, sille on kuitenkin tyypillistä polaarisuus, monologisuus ja aggressiivisuus (Matikainen, 2011, s. 95-96; Meyers, 2010, s. 268, 317). Matikainen (mp.) jopa väittää, että verkkokeskusteluissa esitetään kärjekkäämpiä kannanottoja kuin verkon ulkopuolisessa todellisuudessa. Tähän lienee osasyynä foorumeille tyypillinen anonymiteetti, jonka turvin on mahdollista tuottaa sellaisiakin viestejä, joita ei omalla nimellä esittäisi. Viesteillä voi olla suuri vaikutus lukijoiden mielipiteisiin sen lisäksi, että ne voivat ylläpitää myös pelkoa ja vihamielisyyttä (Opetusministeriö, 2016, s. 128, 130), joten ei ole yhdentekevää, millaisia viestejä verkkoon kirjoitetaan. Äärimmäisessä tapauksessa keskustelu voi saada verkkovihan ja vihapuheen piirteitä.

Seksuaalivähemmistöt ovat syrjittyjä heteronormatiivisessa yhteiskunnassa, vaikka monissa valtioissa ja aloilla (mm. puolustusvoimissa ja urheilussa) suhtautuminen onkin muuttunut myönteisemmäksi (Anderson 2011a; Hajek \& Giles, 2005, s. 164; Herek, 2002; heteronormatiivisuudesta yhteiskunnissa, ks. esim. Herz \& Johansson, 2015). Kun arvohierarkiassa ylimpänä normikategoriana on yksiavioinen, sukupuolinormeja noudattava ja lisääntymiseen pyrkivä heteroseksuaalisuus (Cameron \& Kulick, 2006, s. 165; Coates, 2013), on ns. normipoikkeamien kohtalona olla hierarkiassa toisarvoisia ja syrjittyjä sekä erilaisten vähemmistöfobisten ja vääristyneiden asenteiden ja oletusten kohteita (kuten pedofilian ja psyykkisten ongelmien liittäminen homomiehiin, ks.
Herek, 2002; Soininen, 2015). Tämä vastakohtainen tilanne luo pohjan myös tämän artikkelin tutkimusasetelmalle.

Seksuaalivähemmistöt kohtaavat usein affektiivista nonverbaalista ja verbaalista väkivaltaa (ks. esim. Hajek \& Giles, 2005; Meyer, 2012), ja verbaalinen väkivalta voimakkaana diskursiivisena vallankäyttönä voi jättää pysyvämmät jäljet kuin fyysinen (Meyer, 2012, s. 863). Asenteet todellistuvat homofobisuutta ilmentävinä, pejoratiivisina affektiivisina ilmauksina, homohysteriana eli heteroseksuaalin pelkona tulla identifioiduksi homoseksuaaliksi (Anderson, 2011b; Armstrong, 1997; Pascoe, 2005), heteroseksistisenä kielenkäyttönä (Cameron \& Kulick, 2006, s. 537-358) kuin myös niin sanottuina mikroaggressioina, kuten yliseksualisoivana kielenkäyttönä (Platt \& Lenzen, 2013). Siten affektiivisuus ei ole aina selvästi näkyvää tai edes tarkoituksellista, vaan eksplisiittisen diskriminoinnin lisäksi se voi olla havaitsematonta ja arkista. Sen sijaan julkista keskustelua käydään runsaasti esimerkiksi parlamenteissa lainsäädäntötyön yhteydessä (ks. Bachmann, 2011; Baker, 2004a), ja tätä käsittelyä raportoidaan ajankohtaisina uutisina ja käsitellään keskusteluohjelmissa ja lehdissä (ks. Juvonen, 2004; Katila, 2011; Matikainen, 2011; Tolvanen, 2007). Näin keskusteluista ja asenteista tulee laajasti näkyviä ja siten osa yhteiskunnallista jaettua sosiaalista toimintaa. Juvonen (2004, 2015, s. 20) kuitenkin myös korostaa, että niin sanottu kaapittaminen eli seksuaalivähemmistöön kuulumisen ohittaminen on myös marginalisoivaa ja syrjivää (näkymättömyydestä ja marginalisoinnista myös Soininen, 2015).

Mediaan (mm. Faulkner, 2006; Juvonen, 2002, 2004; Katila, 2011; Tolvanen, 2007) ja yhteiskunnalliseen keskusteluun (mm. Bachmann, 2011; Baker, 2004a; Charpentier, 2000, 2001; Cooper, 2004; Faulkner, 2006; 
Morrish, 1997) liittyvissä tutkimuksissa havaittuja homouteen ja homoihin toistuvasti liittyviä diskursseja ovat muun muassa tasavertaisuuden ja laillisuuden, yhteiskunnallisen hyödyllisyyden, vaaran ja rappion, luonnollisuuden ja luonnottomuuden, eksotisoinnin, seksualisoinnin, kriminalisoinnin, sairauden ja uskonnon diskurssit. Heterodiskursseja ei tästä näkökulmasta ole tutkittu, koska kiinnostavampaa on ollut tarttua niin sanottuun ei-normiin. Baker (2005) ja Coates (2013) ovat kuitenkin havainneet, että heteroista puhuttaessa yhtäältä toistetaan "normaaliuden" diskurssia ja korostetaan henkilöiden hyviä piirteitä (normal, happily married, sober, good-looking) ja toisaalta heteroseksuaaliset diskurssit toistavat perinteistä käsitystä kunnollisesta ja soveliaasta feminiinisyydestä ja maskuliinisuudesta (yksiavioisuus, ydinperhe, lapset, harrastukset...).

Käsillä olevassa tarkastelussa keskitytään nimenomaan keskustelupalstan toistuviin ja tyypillisiin homouteen ja heterouteen liittyviin diskursseihin, ja siinä yhdistetään määrällinen ja tilastollinen analyysi laadulliseen diskurssien tutkimukseen. Aineiston ei voi katsoa edustavan koko suomalaista yhteiskuntaa, sillä keskustelupalstan kirjoittajista puuttuvat monet ryhmät: ne, jotka eivät käytä verkkoa mielipiteidensä kertomiseen tai tiedon jakamiseen; ne, joilla ei ole teknisiä mahdollisuuksia tai valmiuksia käyttää verkkopalveluja; monet nuoret, jotka viestivät muilla foorumeilla, ja niin edelleen. Vaikka käyttäjäkyselyn (Ruckenstein 2017) mukaan tyypillisiä Suomi24:n käyttäjiä ovat kaupunkilaiset keski-ikäiset miehet, jotka ovat "varsin tyytyväisiä omaan elämäänsä, ihmissuhteisiinsa ja yhteiskunnalliseen asemaansa", tutkimusaineisto on kuitenkin erittäin laaja ja käyttäjiensä ominaisuuksien näkökulmasta monipuolinen, joten sen avulla voidaan päästä kiinni ainakin osittain yhteiskunnalliseen kansalaiskeskusteluun.

\section{KORPUSAVUSTEINEN DISKURSSINANALYYSI (CADS) JA FRASEOLOGISUUS}

Tutkimus toteutetaan korpusavusteisen diskurssianalyysin (corpus-assisted discourse studies, CADS) avulla ja tarkastelemalla hakusanojen fraseologisia ominaisuuksia. Diskurssit voidaan määrittää yhtäältä rakenteellisesta näkökulmasta yhtä lausumaa tai virkettä pitemmiksi merkityksen sisältäviksi tekstijaksoiksi tai toisaalta funktion ja sosiaalisen toiminnan näkökulmasta kielenkäytöksi, jossa merkitykset syntyvät, vakiintuvat ja muuttuvat. Oleellista on, että merkitykset rakentuvat nimenomaan yhteiskunnallisessa ja sosiokulttuurisessa vuorovaikutuksessa ja muodostavat jaetun repertuaarin; se, mistä ja miten puhumme, on pikemminkin yhteistä, toisteista ja säännönmukaista jaettua todellisuutta kuin uniikkeja lausumia (Cameron, 2001, s. 15; Pietikäinen \& Mäntynen, 2009, s. 24, 26-27; Partington, Duguid \& Taylor, 2013, s. 2). Diskurssit tekevät yhteiskunnan ilmiöt näkyviksi ja toisaalta myös edelleen muokkaavat tai vahvistavat olemassa olevaa keskustelua (Barker, 2003, s. 102). Käsillä olevassa tutkimuksessa diskursseja lähestytään molemmista edellä mainituista näkökulmista: Ensinnäkin tutkimuksen lähtökohtana ovat yksittäiset seksuaaliryhmien nimityksiksi vakiintuneet ilmaukset, joita tarkastellaan niiden käyttöympäristössä esiintyvien tekstuaalisten kytkentöjen näkökulmasta. Toisaalta kielenkäyttöä lähestytään myös sosiaalisesta näkökulmasta, kun Suomi24-keskusteluja tarkastellaan nimenomaan sosiaalisten, keskustelupalstan käyttäjien jakamien merkitysten kautta. Keskusteluihin osallistuessaan kirjoittajat tekevät kielellisiä valintoja, jotka liittävät keskustelun aiempiin kielenkäyttötilanteisiin ja yhteiskunnallis-sosiaalisiin rakenteisiin (ks. Pietikäinen \& Mäntynen, 2009, s. 18-16). 
Korpusavusteinen diskurssianalyysi yhdistää kaksi lähtökohdiltaan erilaista tarkastelutapaa: pohjimmiltaan laadullinen ja suhteellisen pieniin aineistoihin keskittyvä diskurssintutkimus (ks. Baker, Gabrielatos, KhosraviNik, Krzyzanowski, McEnery \& Wodak, 2008, s. 273; Pietikäinen \& Mäntynen, 2009, s. 139-140; Stubbs, 1997, s. 107) saa rinnalleen korpustutkimuksen laajoihin tekstimassoihin perustuvat, pääasiassa määrälliset menetelmät (ks. Baker, 2006; Baker ym., 2008; Mautner, 2009). Molemmille lähestymistavoille on yhteistä se, että niissä tarkastellaan todellisia kielenkäyttäjien tuottamia tekstejä ja luodaan päätelmiä nojautuen säännönmukaisuuksiin ja toistuvuuteen.

Tarkastelussa hyödynnetään myös kielen inherenttiä ominaisuutta, fraseologisuutta (ks. esim. Granger \& Meunier, 2008; Hunston, 2001; Jantunen 2009), jolla tarkoitetaan sitä, että kielen ilmaukset eivät "elä" tyhjiössä vaan niitä käytetään niille tyypillisissä tekstikonteksteissa ja käyttöyhteyksissä. Nämä ilmausten - esimerkiksi sanojen - tyypilliset käyttötavat reaalistuvat kielenkäytössä toisteisina rakenteina, minkä huomaa helposti esimerkiksi synonyymisiä sanoja vertailemalla: naiset, tytöt, päivät ja unet ovat tyypillisesti kauniita, mutta miehet ja autot sen sijaan komeita. Fraseologisuus koskee kuitenkin myös muita kontekstissa olevia piirteitä kuin sanatason myötäesiintymiä eli kollokaatioita, ja tutkimuksissa fokusoidaankin usein kollokaatioiden lisäksi myös niin sanottuihin semanttisiin preferensseihin. Niillä tarkoitetaan ilmiötä, jossa ilmaukset saavat ympäristöönsä tiettyjä samaan merkitysryhmään kuuluvia sanoja (esim. yllä mainitun kaunissanan ympäristössä on tavallisesti mm. säähän ja naissukupuoleen liittyviä ilmauksia; ks. myös Jantunen 2009; 2017). Fraseologisuudella ei tässä tutkimuksessa tarkoiteta siis ainoastaan perinteisesti fraaseiksi luokiteltuja ilmauksia, kuten Eiole kaikkimuumit laaksos- sa ('ei ole kovin älykäs' tms.) tai Itku pitkästä ilosta.

Kuten diskurssianalyysissa ja korpustutkimuksessa myös fraseologisten rakenteiden todentamisen ehtona on toisteisuus ja säännönmukaisuus: jotta jollakin ilmauksella voidaan väittää olevan taipumus esiintyä esimerkiksi tietyssä merkitysympäristössä, on esiintymisen oltava säännönmukaista ja frekventtiä eikä vain satunnaista. Niinpä tässäkin tutkimuksessa kiinnitetään huomiota erityisesti niihin piirteisiin, jotka kertovat toisteisesta kielenkäytöstä: taajaan esiintyvien ja tilastollisesti merkitsevien avainsanojen ja niiden merkitysryhmittelyn avulla pureudutaan Suomi24:ssä yhteisesti jaettuun sosiaaliseen tietoon, kokemuksiin, merkityksiin ja asenteisiin.

\section{SUOMI24-AINEISTO JA AVAINSANAT}

Alkujaan 90-luvun sähköpostiviestien ja suljettujen keskustelupalstojen analyysistä syntynyt digitaalisten diskurssien tutkimus (ks. esim. Beißwenger \& Storrer, 2008; Beißwenger, Oostdijk, Storrer \& van den Heuvel, 2014; Giles, Stommel, Paulus, Lester, \& Reed, 2015) hyödyntää nykyisin yhä laajempia aineistoja, mistä on esimerkkinä tämänkin tutkimuksen Suomi24-korpus, joka sisältää tekstejä Suomi24-keskustelufoorumilta vuosilta 2001-2015². Aineisto on koottu

2 www.suomi24.fi. Foorumi on Aller Oy:n omistama, kaikille avoin, maksuton verkkokeskustelukanava, joka on osa laajempaa Suomi24-verkkoyhteisöä. Keskusteluun voi osallistua sekä omalla nimellä että nimimerkillä aloittamalla keskusteluketjun tai kommentoimalla olemassa olevaa ketjua. Palstan ylläpito moderoi keskustelua, ja se voi oman harkintansa ja käyttäjien tekemien ilmoitusten perusteella poistaa asiattomat ja Suomen lakia rikkovat viestit, esimerkiksi rasistiset tai väkivaltaan kiihottavat viestit. Palveluun kuuluu lukuisia teemoitettuja keskustelualueita, kuten matkailu, harrastukset, koti, terveys, perhe ja seksi. (Lagus ym., 2016; Suomi24.) 
Kielipankkiin ${ }^{3}$ Korp-hakukäyttöliittymän ${ }^{4}$ kautta saatavilla olevaksi tutkimusaineistoksi. Se sisältää 2,4 miljardia sanetta, 48 miljoonaa tekstiä ja 231 miljoonaa virkettä (Lagus ym., 2016; Meta-Share, 2016). Tätä tutkimusta varten korpuksesta on koottu keväällä 2016 kaksi osakorpusta hakemalla koko korpuksesta sanat homo ja hetero taivutusmuotoineen ja kappaleen laajuisine tekstikonteksteineen. Kappaleen pituus vaihtelee muutamasta saneesta yli sadan saneen mittaisiin tekstijaksoihin. Aineistosta on näin saatu laajempi kuin Korpin virkerajauksella. Keskittyminen vain näihin sanoihin jättää tutkimuksen ulkopuolelle runsaan joukon muita sanoja, joilla seksuaaliryhmiä nimitetään (mm. homoseksuaali [nen], hintti, heteroseksuaali [nen], hetsku), mutta valinta on perusteltu, koska menetelmän vuoksi artikkelin mittaisessa tutkimuksessa ei ole mahdollista tuottaa analyysia useista ilmauksista. On syytä huomata, että valittuja sanoja ei käytetä kielessä samalla tavalla: homo-sanalla voidaan viitata sekä seksuaalivähemmistön edustajaan että henkilöön tai asiaan, jota keskustelija väheksyy tai pitää moitittavana (Lehtonen 2003, s. 145-146), mutta heterosanaa ei käytetä jälkimmäisellä tavalla. Tässä mielessä ilmaukset ovat epäsymmetrisiä, mitä käsitellään artikkelissa myöhemmin.

Tutkimukseen valittujen sanojen frekvenssit poikkeavat selvästi toisistaan: homo $\mathrm{n}=376$ 000 ja hetero $\mathrm{n}=89000$ (vrt. homoseksuaali $\mathrm{n}=37000$ ja heteroseksuaali $\mathrm{n}=3000)$. Homo on selvästi yleisempi, mikä on linjassa Bakerin (2005, s. 89) havainnon kanssa siitä, että tunnusmerkitöntä heteroseksuaalisuutta ei kielennetä kovin usein. Aineistonmuodostuksen lähtökohdaksi otettiin hetero-sanat kappalemittaisine konteksteineen, jolloin aineisto muodostui noin 2,3 miljoonan saneen

3 https://www.kielipankki.fi

4 https://korp.csc.fi kokoiseksi. Suunnilleen samankokoiseen homoaineistoon päädyttiin systemaattisen otannan avulla ottamalla analyysiin mukaan joka neljäs Korpin-käyttöliittymän tuottama konkordanssisivu (1000 esiintymää / sivu). Aineistosta poistettiin tämän jälkeen selvästi havaittavat toisteiset ketjut (esim. HOMO HOMO HOMO HOMO HOMO HOMO) ja usein toistuvat tekstijaksot (mm. viestiketjujen aiempien viestien identtiset toistot). Näin lopullinen tutkittavien tapausten määrä on 109000 homo-sanaa ja 72000 hetero-sanaa konteksteineen. Aineisto on lemmatisoimaton (eli sananmuotoja ei ole liitetty lekseemien perusmuotoihin). Lemmatisoimattomuus mahdollistaa pääsyn alkuperäisiin käsittelemättömiin viesteihin, joskin luo toisteisuutta avainsanalistaan, koska siinä toistuvat jotkin saman lekseemin taivutusmuodot. Koska tarkasteltavana on kuitenkin iso joukko avainsanoja, ei yksittäisten sanojen useampien taivutusmuotojen pääsy listalle muodosta ongelmaa analyysin kannalta.

Aineisto on analysoitu aluksi ns. avainsanaanalyysin (keyword analysis) avulla. Avainsanoilla tarkoitetaan ilmauksia, jotka esiintyvät tutkimusaineistossa epätavallisen taajaan vertailuaineistoon verrattuna ja jotka siten kuvaavat tutkimusaineistoa sanaston näkökulmasta (Scott \& Tribble, 2006, s. 58-59; ks. myös Bondi \& Scott, 2010; Jantunen 2012). Tässä tutkimuksessa hetero- ja homoaineistot toimivat toistensa vertailuaineistoina. Queertutkimuksessa korpusavusteista menetelmää on hyödynnetty aiemmin esimerkiksi miesten online-seuranhakupalstoihin (Milani 2013) ja avainsana-analyysia erityisesti Englannin parlamentin ala- ja ylähuoneissa käytyjen samaa sukupuolta olevien seksisuhteiden suojaikärajaan (Baker, 2004b) ja parisuhteiden rekisteröintiin (Bachmann, 2011) liittyvien diskurssien tutkimisessa. Omassa tutkimuksessani potentiaalisia avainsanoja ovat siis kaikki homo- ja hetero-sanojen kap- 
paleen mittaisissa konteksteissa olevat sanat, jos ne esiintyvät ympäristössä merkitsevästi taajemmin kuin vertailuaineiston konteksteissa. Tutkimuksessa avainsanat toimivat signaaleina eri diskursseista, ja ryhmittämällä sanat merkitysryhmiin (eli semanttisiin preferensseihin) saadaan selville diskurssipotentiaaleja; avainsanat yksinään eivät luo mitään diskurssia mutta juuri ryhmittelyn avulla päästään kiinni sosiaalistuneisiin merkityksiin ja puhetapoihin. Avainsana-analyysi on tehty AntConc-korpusohjelmiston (Anthony, 2015) avulla.

Tutkimukseen on otettu mukaan 500 tilastollisesti merkitsevintä avainsanaa molemmista aineistosta ja ryhmitelty sanat merkitysluokkiin niiden kontekstissa saaman merkityksen mukaan. Luokittelu on tehty aineistolähtöisesti eli on vältetty valmiita merkitysluokkia ja luotu nimenomaan ryhmiä, jotka nousevat aineistosta. Oheisessa taulukossa 1 on lueteltu esimerkkinä homoaineiston 20 merkitsevintä avainsanaa heteroaineistoon verrattuna. Taulukko kertoo, että homo-sanan tekstiympäristössä on tilastollisesti enemmän sananmuotoja vitun, vittu, kirkko, S/suomen, kirkon, jumalan, paskaa jne. kuin heteroaineistossa hetero-sanan tekstiympäristössä. (Avainsanana esiintyy myös luonnollisesti homo - samoin kuin heteroaineistossa hetero - mutta koska tutkimus keskittyy nimenomaan sanojen kontekstiin, on sanat poistettu taulukosta.) Taulukon sanoja ryhmittelemällä huomaa, että homo-sanan ympäristössä näyttäisi esiintyvän mm. uskontoon liittyvää sanastoa sekä alatyylisiä ilmauksia (jälkimmäisiin lukeutuu myös heitä, silloin kun se on verbin taivutusmuoto idiomissa beitä homo voltti eikä pronomini). Seuraavassa luvussa esitetään avainsanojen luokittelusta saatava kuva homo-ja hetero-sanojen käytöstä ja tähän nojautuen tarkastellaan, millaisia ovat tyypillisimmät homouteen ja heterouteen liittyvät diskurssit Suomi24-keskustelupalstalla.
Taulukko 1. Homoaineiston 20 merkitsevintä kontekstissa esiintyvää avainsanaa (avainsanaisuusarvo on laskettu log-likelihood-testin avulla).

\begin{tabular}{|l|l|l|}
\hline Avainsana & Määrä & $\begin{array}{l}\text { Avainsanai- } \\
\text { suusarvo }\end{array}$ \\
\hline vitun & 1252 & 773,5 \\
\hline vittu & 1184 & 669,9 \\
\hline kirkko & 1399 & 503,4 \\
\hline kirkon & 1405 & 404,8 \\
\hline Suomen & 1444 & 387,6 \\
\hline jumalan & 2380 & 359,2 \\
\hline paskaa & 705 & 313,3 \\
\hline saatana & 451 & 298,1 \\
\hline saatanan & 524 & 275,7 \\
\hline raamatun & 1227 & 236,3 \\
\hline ateistit & 323 & 230,1 \\
\hline ja & 76863 & 225,5 \\
\hline jumala & 2356 & 225,0 \\
\hline paska & 456 & 215,4 \\
\hline syö & 338 & 212,0 \\
\hline heitä & 1744 & 194,2 \\
\hline vastaan & 2202 & 177,6 \\
\hline Suomessa & 1331 & 167,8 \\
\hline vihaa & 737 & 165,9 \\
\hline haista & 184 & 156,4 \\
\hline
\end{tabular}

\section{AVAINSANOJEN LUOKITTELU JA AINEISTON YLEISIMMÄT DISKURSSIT}

\section{Homot, uskonto ja tämän maan poliitikot}

Cameron (2001, s. 15) korostaa, että yhteen yhteiskunnalliseen tai sosiaaliseen ilmiöön liittyy yleensä useita samanaikaisia diskursseja. Niitä ei myöskään ole mitään ennalta määrättyä määrää (Sunderland, 2004, s. 3). Näin on tässäkin tutkimuksessa: tarkasteltujen aineistojen 500 avainsanaa jakautuvat useisiin 
merkitysluokkiin: esimerkiksi homoaineiston analyysi tuottaa 22 erilaista merkitysluokkaa, joista pienimpien osuus jää vain noin yhteen prosenttiyksikköön. Keskityn seuraavassa tulosten esittelyssä vain osuuksiltaan suurimpiin luokkiin.

Ensimmäisessä vertailussa tarkastellaan homoaineistoa. Vertailu heteroaineistoon osoittaa, että viiteen suurimpaan merkitysluokkaan voidaan lukea peräti $72 \%$ kaikista 500:sta mukaan otetusta avainsanasta. Nämä preferenssit ovat osuuksineen seuraavat: uskonto $(20,2 \%, n=101)$, ihmiset $(16,4 \%$, $\mathrm{n}=82)$, aggressio $(16,0 \%, \mathrm{n}=80)$, paikka $(10,0 \%, n=50)$ ja politiikka $(9,0 \%, n=45)$. Tulos kertoo täten siitä, että kun Suomi24keskusteluissa puhutaan homoista, keskusteluissa käsitellään samanaikaisesti myös uskontoa, politiikkaa, ihmisiä ja paikkoja tai tekstikontekstissa on ilmauksia, joista syntyy aggressiivinen tulkinta. Käsittelen näitä diskursseja seuraavassa tarkemmin.

\section{Uskonto-diskurssi}

Suomi24-keskusteluissa uskonto-diskurssia tuottavia tyypillisiä ilmauksia ovat kirkko, Raamattu, uskonto ja uskova, Jumala ja Jeesus (esimerkit 1-5)5. Uskonto-diskurssi homoista puhumisen yhteydessä ei ole kovin yllättävä aiemman tutkimuksen perusteella, sillä myös Charpentierin $(2000,2001)$ lesbo- ja homoliittoja koskevaa mielipidekeskustelua tarkastelevassa tutkimuksessa kristillinen diskurssi erottautuu yhdeksi valtadiskurssiksi. Oma tutkimukseni paljastaa diskurssin kuitenkin laajemmaksi kuin vain kristillisyyteen liitty-

5 Aineistoesimerkit eivät muodosta keskustelukokonaisuuksia toistensa kanssa eivätkä ole peräisin samoista keskusteluketjuista. Ne ovat alkuperäisessä asussaan mm. kirjoitusvirheineen. Kirjoittajien anonymiteetin säilyttämisen vuoksi esimerkeissä ei ole yksilöintitietoja, koska tunnistetieto (kuten nimimerkki) voi olla käytössä myös muissa verkkopalveluissa (ks. Lagus, ym. 2016, s. 38.) väksi ja esimerkiksi syntiä ja irstautta korostavaksi, sillä uskontoa käsitellään keskusteluissa monitahoisesti, kuten myöhemmät esimerkit (6-8) osoittavat.

1) Kirkko tarvitsee lisää homoiksi kouluttajia, ehkä piispoilla on vähemmän käytettyjä takamuksia kun itse ilmeisesti ovat käyttäjiä --.

2) Jumala ei luonut homoja! Jumala tuominnut homoot, joka on kirjoitetuna Raamattuun! Pyhä Henki on ilmoittanut, että homot ei peri Jumalan Valtkuntaa!

3) Kaikkein oudointa ja hölmöintä homoilta on esittää vaatimuksia instituutioille, kuten kirkko, jonka perustus on uskonto.

4) Jeesus ei siis sano homon ja heteron avioliitosta mitään.

5) Kautta aikojen on ollut transuja, homoja jne. Jumala on luonut heidät eivätkä he mihinkään häviä vaikka uskovaisten missiona on tasapäistää kaikki samaan kastiin kuuluviksi heteroiksi.

Yllä olevista esimerkeistä näkee, että uskontoon liittyvää sanastoa esiintyy sekä homouteen kielteisesti (1-3), neutraalisti (4) tai myönteisesti (5) suhtautuvien teksteissä. Uskontotematiikkaan liittyvä sanasto myös kertautuu ja varioi viesteissä, mikä on luonnollista, koska samaan merkitysryhmään kuuluvilla sanoilla perustellaan näkemyksiä laajasti. Taajaan esiintyviä uskontotematiikkaan kytkeytyviä avainsanoja ovat myös pappi ja naispappi/pappeus. Näissä tapauksissa keskustellaan muun muassa siitä, voisiko pappi vihkiä homoja (6) tai homo toimia pappina (7). Lisäksi on tyypillistä, että homous nostetaan yhdeksi ongelmaksi tai synniksi (ks. myös Charpentier 2001), johon kirkon on otettava kantaa muiden ilmiöiden, kuten naispappeuden, rinnalla (8). Verkkoyhteisön kansalaiskeskustelut vahvistavat, että homoseksu- 
aalisuuden epäoikeuttaminen mm. uskonnon varjolla (ja heteroseksuaalisuuden pyhyys, ks. Charpentier 2000) on edelleen voimissaan.

6) Jos olisin pappi niin en ikipäivänä tulisi vihkimään homoja. Ja jos joku haluaa homoilla niin poissa julkisuudelta. Raamattukin sen sanoo että mies on luotu naiselle...

7) Paavi Francicscus todellakin sanoi jotakin uutta. Hän kertoi hyväksyvänsä homot katolisen kirkon papeiksi. Hänen edeltäjänsä Benedictus XVI allekirjoitti asiakirjan, jossa kielletään homoilta oikeus pappeuteen.

8) Voi olla, että pyhäisin työskentely, avioerot, ja naispappeus ovat paljon helpommin hyväksyttävissä synteinä kuin homot yleensä. Ja sitten se vihkiminen olisi kaikkein pahin asia --.

Lisäksi on tavallista, että uskontodiskurssissa käsitellään myös uskontokuntia tai niihin kuuluvia ihmisiä. Näissä puheenvuoroissa otetaan tyypillisesti kantaa siihen, miten eri uskontokunnat suhtautuvat homoseksuaalisuuteen (9-11), tai homot rinnastetaan ihmisryhmiin, kuten maahanmuuttajiin ja juutalaisiin, jotka kohtaavat yhteiskunnassa vainoa (12). Homojen rinnastaminen toisiin (vähemmistö)ryhmiin on verkkokeskustelussa hyvin tyypillistä, kuten seuraavankin diskurssin käsittelyssä käy ilmi.

9) No siis Islamin mukaan homot tulee hirttää ja kristinuskon mukaan homot tulee kivittää kuoliaaksi etten kyllä menisi puolustelemaan kristinuskoa sen enempää kuin Islamia.

10) Aikoinaan kristityt panivat homoja roviolle palamaan, nyt Venäjällä ortodoksikritsityt hyökkäävät homojen kimppuun väkivalloin ja Ranskassa katoliset. Onneksi luterilaiset ovat nynnyjä.
11) Toisin sanoen ei haittaa jos muslimit saarnaa vihaa homoja vastaan, mutta suomalainen ei saa sanoa mitään.

12) Yllyttäminen maahanmuuttajien, juutalaisten, homojen ja värillisten tappamiseen on rikos.

\section{Henkilö- ja ryhmädiskurssit}

Seuraavaan merkitysryhmään - ihmiset ja ryhmät - lukeutuvat sekä ihmisviitteiset pronominit, yksittäisiin ihmisiin viittaavat erisnimet sekä ihmisryhmät, jotka eivät ryhmity esimerkiksi uskontoteeman alle. Pronominit (kuten sinä, he, te) ovat toki tavallisia, mutta eivät kuitenkaan yksin selitä tämän luokan suurta osuutta. Homouden yhteydessä käsitelläänkin taajaan nimenomaan ihmisryhmiä ja yksittäisiä henkilöitä, joihin homot rinnastetaan (ks. myös edellä) tai joiden suuntautumisesta keskustellaan. Ihmisryhmistä nousevat esiin etenkin maahanmuuttajat, ruotsalaiset, feministit ja sivarit (13-15) ja yksittäisistä henkilöistä Antti (Tuisku), Pekka Haavisto, Tarja Halonen, (Sauli) Niinistö ja Päivi Räsänen (13, 16-18), joista Tuiskua lukuun ottamatta muut ovat poliitikkoja. Heihin kohdistuva keskustelu kumpuaa yhteiskunnassa vallalla olevasta muutoksesta, homoseksuaalisuuden käsittelyssä poliittisilla areenoilla ja mediassa ja poliittisen henkilön avoimesta tai epäillystä homoseksuaalisuudesta (ks. myös Juvonen 2015). Keskustelu ei toki ole kuitenkaan aina vähemmistövastaista, vaan mukaan mahtuu vaikkapa ironisia kannanottoja (15) esimerkiksi stereotypioista.

13) Pekka Haavisto lähtee vihreiden ehdokkaaksi ja vasemmisto tukee häntä. Se sopii nykyiselle vasemmistolle hyvin koska lespot ja homot ja maahanmuuttajat, ovat etusialla sitten tulevat vasemmiston hylkäämät duunarit.

14) Kuka voisi auttaa suomea? Suomessa jyl- 
lää homot, naispapit ja feministit. Tarkkailuluokat täynnä kaiken maailman avustajia ja psykologeja.

15) Tuollaisen mielestähän kaikki venakot on juoppoja, kaikki ruotsalaiset homoja, kaikki suomalaiset pellejä, kaikki amerikkalaiset imbessiileja jne.

16) Vaikka kukaan ei alkaisikaan homoksi tai lesboksi, on se Raamatun mukaan synti. Lääketieteellisesti Räsänen osoitti sen myös poikkeavuudeksi.

17) Ei halonen ole koskaan ollut kiinnostunut suomalaisista paitsi suomalaisista homoista ja lesboista.

18) Eli typerät kysymykset siitä onkohan Antti homo, voisi mun puolestani jättää väliin, asia on aika selvä.

\section{Väkivalta- ja vihadiskurssi}

Seuraavaksi suurimman ryhmän muodostavat ilmaukset, jotka voidaan luokitella väkivaltaisiksi teoiksi, niihin kehottamiseksi, vihapuheeksi, haukkumiksi tai voimasanoiksi. Osa viesteistä on (lähellä) kunnianloukkaukselle tyypillistä kielenkäyttöä (mm. huorittelu), ja ne sisältävät myös kansanryhmää vastaan kiihottavia ilmauksia eli täyttävät vihapuheen ja rikoksen tunnuspiirteet. Opetusministeriön (2016, s. 81, 94, 129) selvityksen mukaan häirintä ja suoranainen verkkoviha on yleistä, ja se jopa rajoittaa tiettyjen ihmisryhmien, mukaan lukien seksuaalivähemmistöjen, verkkokäyttöä sen lisäksi, että se aiheuttaa psyykkisiä häiriöitä ja heikentää yleistä turvallisuuden tunnetta ja vaikeuttaa jokapäiväistä elämää (ks. myös Edelstein \& Wolf 2013; Soininen 2015, s. 14-15). Verkkovihaksi määritellään $\mathrm{mm}$. rasismin, uskonnollisen kiihkoilun, naisvihan ja poliittisen vihapuheen lisäksi myös homofobia (Edelstein \& Wolf 2013, s. 8; ks. myös Pöyhtäri, Haar \& Raittila, 2013, s. 19, 49). Suomi24-keskustelufoorumin viesteissä on runsaasti verkkovihan piirteitä, vaikka ylläpitäjät pyrkivätkin moderoimaan viestejä eli arvioimaan niiden julkaisukelpoisuutta ja tarvittaessa poistamaan loukkaavat viestit. ${ }^{6}$ Vihapuhe on kuitenkin vain yksi osa tähän diskurssiin kuuluvasta tematiikasta: esimerkiksi se, miten Raamatussa tai joissakin uskontokunnissa käsketään homot tappaa tai kivittää, muodostaa aineistossa voimakkaasti näkyvää, vihapuhetta laajempaa väkivaltadiskurssia $(19,20)$; kyse onkin eräänlaisesta aiemmin esitetyn (viha)diskurssin intertekstuaalisesta kierrättämisestä keskustelupalstalla.

19) Joten Raamatusta löytyy täten kehoitus tappaa homot.

20) Imaamin mukaan homot on kivitettävä, kaulittava ja käännettävä.

Ylivoimaisen tavallista aineistossa on voimasanan vittu käyttö; se on myös merkitsevin avainsana, ks. taulukkoa 1 . Vitulla lisätään keskustelupuheenvuoron ja määritettävänä olevan ilmauksen (homo) affektiivisuutta $(21,22)$, ja se onkin yksi suomen kielen taajaan käytetty affektiivinen voimasana (ks. VISK \& 1725, 1726). Ilmauksella vitun homo (tai pelkkä homo) ei aina kuitenkaan viitata seksuaaliseen suuntautumiseen vaan ilmausta käytetään loukkaavana nimityksenä kenestä tai mistä tahansa $(21,26)$, johon aggressio halutaan kohdistaa tai jota pidetään huonona (ks. myös Lehtonen 2003, s. 145-146). ${ }^{7}$ On huomattava, että vastaavaa käyttötapaa ei ole hetero-sanalla, mikä voi vaikuttaa voimasanojen määrään homo-sanan

6 Päivittäisistä $15000-20000$ viestistä käsitellään noin tuhat; tutkimusaineistoon poistetut viestit eivät ole päätyneet (ks. Lagus ym. 2016, s. 9). Käsillä olevan artikkelin aineiston moderointitietoja ei ole saatavilla.

7 Armstrongin (1997) ja Pascoen (2005) tutkimuksista käy ilmi, että samaan tapaan esim. englannin gay- ja fag-ilmauksilla on muitakin kuin homoseksuaalisuuteen viittaavia merkityksiä (esim. 'huono, kelvoton') ja funktioita. 
yhteydessä. Myös muut voimasanat, kuten saatana/n, perkele/en, helvetti/in ja paska/a ovat homon yhteydessä taajaan käytettyjä, ja usein ne kasaantuvat viesteissä $(22,23)$.

21) redtube on yhdyssana vitun homo

22) Mua kun ei ole kukaan vitun homo ikinä perseeseen vittu nussinut, että tiedoksi vaan sulle vitun hinttiperseelle vittu se saatana!!!!!!!!

23) haista paska saatanan helsinkilainen mongooli. jos ma sinut joskus naen niin tulee verta sun nenasta perkeleen perse homo.

Muutkin nimittelyt kuin homottelut ovat hyvin yleisiä aineistossa, kuten edellisistäkin esimerkeistä jo näkee. Avainsanoiksi homokeskusteluissa nousevatkin monet nimitykset, kuten huora, hurri, kusipää,pelle, runkkari jne. Näillä viitataan joko homoihin tai muihin ryhmiin, kuten naisiin huora-nimittelyllä (25), tai ruotsalaisiin (26).

24) Heitä homo voltti, pelle olet.

25) Suomenkin pääministerinä on pelkkä halpa huora, onneksi ei sentään pressana ole vikisevää homoa.

26) Hurri homot ei uskalla ärsyttää Pietarin herroja ottamalla Suomea takaisin.

Väkivalta- ja vihadiskurssi rakentuu lisäksi myös ilmauksista, joissa kehotetaan suoranaisiin rikoksiin tai halutaan kohdistaa rikolliset teot esimerkiksi juuri homoja kohtaan. Tällaista diskurssia toisintavat ilmaukset, kuten tappaa, kivittää, ammu/ampuisin, hirteen (27), (antaa/vetää) turpaan (28), työnnä (perseeseen) (30), mutta vihadiskurssia synnytetään myös muilla, vähemmän taajaan esiintyvillä ilmaisuilla (29). Näissäkin tapauksissa homottelun kohteena voi olla joku muukin kuin seksuaalivähemmistöön kuuluva (30). Koska keskustelupalstalla voi esittää mielipi- teensä anonyymisti, voi keskustelu olla hyvinkin aggressiivista provosointia ja vihan lietsomista eli ns. fleimausta nimimerkin takaa (ks. Laaksonen \& Matikainen 2015).

27) Oi tää irstas kansa mitä se tekee, huh huh. Heitä ittes hirteen homo.

28) Heilu sinä vaan siellä stadissasi homojesi parissa. jos teitä tänne maaseudulle ilmaantuu niin turpaan vedetään ja täysillä.

29) Kaikki homot, mamut, lesbot, gayt ajettava mereen heti kun ne sulaa.

30) Aivan täyttä paskaa jauhat, että työnnä sinä homo vaikka se vasara perseeseen ja jää työttömäksi.

\section{Poliittinen diskurssi}

Kun homoutta käsitellään, on politiikka usein esillä. Tämä on luonnollista paljolti siksi, että tasavertaisuuteen ja oikeuksiin liittyviä lakimuutoksia käsitellään juuri poliittisissa instituutioissa, jolloin puolueiden ja yksittäistenkin poliitikkojen julkilausumat näkemykset herättävät halun kommentointiin. Toinen kommentointia ruokkiva tilanne on vaalit, etenkin jos ehdolla on avoimesti homoseksuaaleja. Poliittisella kentälläkin käyty homokeskustelu voi saada jopa vihapuheen piirteitä ja koskea yksittäisiäkin henkilöitä (ks. Juvonen, 2015, s. 154-163). Myös Suomi24-keskusteluissa politiikka-kenttään kuuluvia ilmauksia on paljon. Homoista käyty yleinen keskustelu on siis selvästi politisoitunutta (ks. myös Juvonen, 2004). Keskustelu keskittyy yhtäältä puolueita ja poliittisia ryhmittymiä koskeviin diskursseihin, jolloin taajimmin käsitellään vihreitä, kokoomusta ja perussuomalaisia (31-33). Puolueista ja poliittisista instituutioista (34-36) käydään keskustelua erityisesti eduskunta- ja presidentinvaalien yhteydessä, mikä näkyy keskusteluissa äänestämisen, eduskunnan ja presidenttiyden 
runsaana käsittelynä. Tähän liittyvät myös edellä käsitellyt henkilödiskurssin tapaukset, joissa henkilö on poliitikko (esimerkit 13, 16, 17). Diskurssit kietoutuvatkin yhteen niiltä osin, kun puhutaan poliittisista henkilöistä.

31) Ja vasemmistolla ja vihreille on tärkeintä, että homot saavat mennä naimisiin.

32) Minä ainakin olen aina äänestänyt Kokoomusta ja olen täysin hetero enkä voi sietää tuollaista homojen pakkosyöttöä.

33) Onhan se nyt tiedetty jo pitkään, persut ovat tosimiesten puolue- muut ämmiä, homoja ja mamuja varten.

34) Ei Suomelle mitään tapahdu jos homo presidentti, kun eduskunta päättää asiat eikä presidentti.

35) Olisi ollut suuri häpeä koko Suomelle homo pressa. Onneksi kansa äänesti Niinistöä.

36) Ihmistä, presidenttiä, kai pitäisi nyt äänestää, eikä heteroa tai homoa (eikä edes presidentin puolisoa).

\section{Paikkadiskurssi}

Omaleimainen ja ehkä aluksi yllättäväkin tapa puhua seksuaalivähemmistöistä on liittää vähemmistöt johonkin paikkaan. Avainsanoista joka kymmenes ilmaisee nimittäin jonkinlaista paikkaa. Tavallisimpia sanoja ovat maa (37) sekä valtioiden nimet, kuten lähinaapurimme Ruotsi ja Venäjä (38), joiden oloihin Suomea usein verrataan. Keskustelussa ovat esillä myös Iran ja Israel, muslimimaat ja Uganda, jotka liittyvät osittain maahanmuuttoteemaan ja uskontodiskurssiin. Paikkadiskurssia rakennetaan muun muassa keskusteluissa, joissa käsitellään jonkin kaupungin tai maan ilmapiiriä tai lainsäädännöllistä suvaitsevaisuutta sekä homojen mahdollisuutta elää avoimesti homona tai parisuhteessa. Keskusteluissa viljelläänkin suomalaisia kaupunkeja, isoja ja pienï, pohdittaessa mm. Helsingin (Hesan),
Lieksan ja Turun homoskeneä (39-40). Oma tyyppinsä paikoista puhumisessa ovat konkreettiset paikat, kuten keskitysleiri, koulu ja poikakoulu. Näistä keskitysleirin voisi sijoittaa myös ilmauksiin, jotka tuottavat vihadiskurssia. Koulu esiintyy keskusteluissa usein silloin kun puhutaan, millainen rooli homoudella tai suvaitsevaisuuskasvatuksella pitäisi koulussa olla (42) tai kun keskustelija haluaa jakaa homouteen ja koulumaailmaan liittyviä kokemuksiaan (43). Poikakoulut liittyvät taasen keskusteluun, jossa käsitellään homouden ja poikien hyväksikäytön yleisyyttä näissä instituutioissa (44).

37) Oikein hyvä jos löytää homon parisuhteeseen. Mutta Suomi on iso ja harvaan asuttu maa, joten se ei aina helppoa.

38) Venäjällä ei sentään siedetä homoja kuten Suomessa ja varsinkin Ruotsissa.

39) Onko helsingissä homoja, vai kaikki kaapissa??

40) Myös Lieksan homot ovat ajoittain ottaneet kantaa asioihin ja järjestäneet tapaamisia.

41) Te homot vaa haluutte et m uskottais toi että voitte raiskata meitä, keskitysleirit päälle ja homot sinne jonoissa!

42) Setalle tulee myös asettaa porttikielto kouluihin. Ei ole oikein, että ihmisoikeusfundamentalistit aivopesevät koululaisia homopropagandallaan, jossa julistetaan lapsille yksipuolisesti homojen etujärjestön hyväksi katsomia asioita.

43) Toivon todella et se tykkäis musta, tänään se iski mulle silmää koulussa en oo varma luulenko mut sille kattoi mua silmiin ja iski silmää. Ja yritän just aatella että homous on normaalia, mut kaikki kaveritkin tekee aina homoläppää, jaa sanoo homoja neideiksi. Kyllä se ottaa joskus vähän voimille.

44) Esim. erään poikakoulun kasvatti kertoi HS:ssä jokin vuosi sitten kokemuksensa 
ja totsi että poikakodista lähtiessään n. $80 \%$ pojista oli homoja.

\section{Heterot ja pohdinta (omasta) seksuaalisuudesta}

Edellä huomattiin, että uskontodiskurssin toteutumat kattavat viidesosan kaikista homokeskustelujen avainsanoista. Lisäksi viiteen yleisimpään diskurssiin on luettavissa lähes 3/4 kaikista diskursseja tuottavista avainsanoista, ja viiden yleisimmän diskurssin osuuksissa on selviä määräeroja (vaihteluväli 11,2 prosenttiyksikköä). Näin ei ole heterodiskursseissa: viiden yleisimmän diskurssin erot ovat hyvin pienet (vaihteluväli 3,4 prosenttiyksikköä), ja niiden yhteenlaskettu osuus on $51,4 \%$, mikä tarkoittaa sitä, että avainsanojen merkitysvariaatio ja sitä myötä myös erilaisten diskurssien variaatio on tässä aineistossa homoaineistoa suurempi. Aineistosta nousevia merkitysluokkia ovat yleisyysjärjestyksessä seuraavat: kognitio $(11,4 \%, n=57)$, tunne $(11,4 \%, n=57)$, seksuaalinen suuntautuminen $(10,4 \%$, $\mathrm{n}=52)$, henkilö/minä $(10,2 \%, \mathrm{n}=51) \mathrm{ja}$ sukupuoli $(8,0 \%, \mathrm{n}=40)$.

\section{Ajattelun ja pohdinnan diskurssi}

Heteroaineistolle on tyypillistä, että heterouden käsittelyn ympärille kasautuu ihmisen psyykkiseen ja mentaaliseen toimintaan liittyviä ilmauksia, jotka kuvaavat mielen sisäisiä tiloja, kognitiota ja tunnetta. Keskusteluissa selvästi erottuvan ryhmän muodostavat kognitioon eli tietoon ja sen käsittelemiseen liittyvät ilmaukset, jotka ovat usein kognitioverbejä (ks. Pajunen, 2001). Tavallisimmat tähän kategoriaan ryhmittyvät avainsanat ovat verbit ajatella, haluta, huomata, kuvitella, luulla, miettiä, tietää ja ymmärtää (45-50). Tämän lisäksi omia näkemyksiä kuvataan usein mm. eksplisiittisellä (minun) mielestä(ni) -rakenteella (51), joka korostaa rakenteellisestakin näkökulmasta keskustelufoorumeiden funktiota oman mielipiteen julkistamiskanavana. Aineiston betero-sanan käyttö poikkeaa homosta siinä, että seksuaalisuutta punnitaan pikemminkin omien havaintojen, oman kokemuksen ja pohdinnan kautta kuin että suuntautumisesta esitettäisiin välttämättä jyrkkiä mielipiteitä. Tässä diskurssissa pyritäänkin nimenomaan pohtimaan rationaalisesti omaa tai muiden seksuaalisuutta ja sen merkitystä sekä kokemuksia ja tuntemuksia.

45) Nyt voisi sitten kysyä, että miten suhtaudut heteroihin, jotka eivät halua tai pysty lisääntymään?

46) Itse olen huomannut, että seksuaalisesti, fyysisiltä tarpeiltani olen lähes kokonaan gay, mutta sosiaalisesti, psyykkisesti lähes kokonaan hetero.

47) Olen todellakin hetero, mulla on jätkäkamu enkä vois kuvitellakkaan harrastavani jotain jonkun muijan kanssa. Mutta en tiedä, kyllä sitä suutelua voisi kokeilla muijankin kanssa...

48) Luulin olevani hetero, seurustelin naisen kanssa ja harjoitin hänen kanssaan seksiä. Mikään siltikään ei maistunut siltä kuin pitäisi.

49) Joskus kyllä olen miettinyt, että koska elämä heterona on niin paljon helpompaa, että pitäisikö ottaa mies, koska kerta siihen kykenen.

50) Itse olen toiminta tasolla täysin hetero, mutta en ymmärrä, mitä väliä on laulajan seksuaalisuudella?

51) Vähän pitäisi siis korjailla suomen lakia. Mielestäni homopareillekin pitäisi sallia samat oikeudet, kuin meille heteroille.

\section{Tunnediskurssi}

Toinen mentaaliseen toimintaan liittyvä taa- 
jaan tuotettu diskurssi heterokeskustelussa on tunnediskurssi. Toisin kuin homoaineistossa, tässä aineistossa tunteiden ja tuntemusten käsittely on runsasta: tunteista puhutaan tunneverbien, kuten ihastua, rakastua, tuntua, kaivata (52-53) (ks. Pajunen, 2001), ja tunnesubstantiivien, kuten kaipuu ja rakkaus (53-54), avulla sekä erilaisilla muilla tuntemuksia kuvaavilla sanoilla. Tunnediskurssille on tyypillistä, että keskustelun on aloittanut tai siihen osallistuu henkilö, joka on epävarma omasta seksuaalisuudestaan (heteroudestaan) tai joka vastaa tällaisen henkilön viestiin. Niinpä näissä viesteissä on usein myös muita seksuaalista suuntautumista ilmentäviä ilmauksia (kuten homo, lesbo), mutta tunnesanat ovat kuitenkin tyypillisiä nimenomaan teksteille, joissa esiintyy hetero-sana. Suomi24foorumi näyttääkin tarjoavan paikan oman epävarmuuden esille tuomiselle ja toisaalta myös vertaistuen saamiselle. Näille viesteille on tyypillistä, että keskustelijat kertovat omista kokemuksistaan ja ihastumisen kohteistaan ja haaveistaan. (Toisenlaisiakin tuntemusten esiintuonteja toki laajassa aineistossa on, (55).) Tavallista on, että tunnediskurssia synnyttäviä ilmauksia kerääntyy yhteen useita (kuten 52-53; rakastua, rakkaus, tykätä, ihastua, tuntua, kiihottaa), lisäksi tähän diskurssiin kietoutuu usein myös kognitiodiskurssi, kuten esimerkin (52) ajattelin. Molemmat tähän mennessä käsitellyt diskurssit kertovat siitä, että heteroudesta puhumisen yhteydessä on ylipäätään tapana pohtia ihmisen seksuaalisuutta.

52) rakastuin yhteen mieheen ja se tykkäs musta mutta samalla huomasin että olin ihastunut tyttöön mutta kun ajattelin sitä ei tuntunut missään. ja kun ajattelin sitä poikaa alko kiihottaa ja kerran olin niillä jja alettiin pussailee olenko homo vai hetero?

53) Onko muille käynyt näin onnettomast, että olette menneet rakastumaan heteroon? Miten (toivottoman) rakkauden voisi unohtaa?

54) Vaikka itse olenkin hetero ilman miehisen kosketuksen kaipuuta olen bi-immeisten kannalla.

55) Te Marskin rakastajathan niitä (piilo)homoja olette. Me oikeat todelliset heterot tunnemme luontaista vastenmielisyyttä ja suurta inhoa tuota viiksekästä hintelää hinttaria kohtaan.

Seksuaalisuuden ja suuntautumisen diskurssi

Jo edellä käsitellyistä diskursseista ja niitä kuvaavista esimerkeistä käy ilmi, että heteroaineistossa käsitellään usein seksuaalisuutta ja seksuaalista suuntautumista. Tähän merkityskenttään kuuluvia avainsanojakin on niin paljon, että on perusteltua puhua erikseen seksuaalisuuden ja suuntautumisen diskurssista. Tämä diskurssi syntyy $\mathrm{mm}$. ilmausten seksuaalinen, seksuaalisuus ja suuntautuminen $(56,60)$ kautta, mutta myös eksplikoimalla suuntautuminen: biseksuaali bi, bisse, homoseksuaali, homo, lesbo, lepakko, lesbonainen (57-59). Näistä ilmauksista nimenomaan seksuaalinen suuntautuminen (60; myös suuntaus, suuntautuneisuus, suuntaumus) muodostaa voimakkaan yhteisesiintymän, joka toistuu keskusteluissa erittäin taajaan. Havainto tukee Bakerin (2005, s. 89) huomiota siitä, että heteroista puhuttaessa on tyypillistä puhua seksuaalivähemmistöistä, mutta ei toisin päin, mikä tukee ajatusta heteroseksuaalisuuden norminmukaisuudesta.

56) heteroilla taas seksuaalisuutta ei tarvitse yleensä se kummemmin määritellä tai miettiä - se vain on, niinkuin muillakin ympärillä olevilla.

57) Toivon sydämeni pohjasta, ettet koskaan lisäänny. Kukaan lapsi, oli kyseessä sitten hetero, bisse tai homo, ei ansaitse sellaista 
piinaa.

58) Kyllä se vain täällä turussakin on niin että homoseksuaalit ovat keskimäärin huomattavasti mukavampaa väkeä kuin heterot, joihin me kaikki itsemme luemme.

59) Lähimpiin ystäviin kuuluu 6 lepakkoa, 2 homopoikaa ja muutamia heteroita, kaveripiiriin lukeutuu sitten heidän kaverinsa, kaverin kaverit, tuttavat ja muut.

60) Mutta oikeasti, miltä sinusta tuntuisi heterona olla ilman että voisit toteuttaa seksuaalista suuntautumistasi? Nuo asiat kuuluvat ihmisen perustarpeisiin.

Seksuaalisuutta käsitellään keskusteluissa hyvin monipuolisesti ryhmien (vähemmistö), kiinnostuksen ja halun ( halu, himo, kiinnostus, mielenkiinto, tunne, veto, vetovoima), toiminnan (byväksikäyttö, kanssakäyminen, käyttäytyminen, toiminta) tai identiteetin (identiteetti, taipumus, orientaatio) ja erilaisuuden (poikkeava, poikkeavuus) näkökulmista (61-64). Seksuaalisuus paljastuu keskustelupalstoilla hetero-sanan avulla tarkasteltuna ja nimenomaan sen kontekstissa siis hyvin monitahoiseksi ilmiöksi: diskursseihin rakentuu laaja kirjo seksuaali-identiteettejä ja tapoja olla seksuaalinen yksilö.

61) Kannattais mennä sit ihan eri baariin joka on heteroille suunnattu. Olen kyllä ihan betero, mutta en koe homoseksuaalisuuden uhkaavan omaa seksuaalista identiteettiäni.

62) Jos olisin seksuaalisesti poikkeava, niin äänestäisin myös, mutta olen hetero, niin en äänestä.

63) Jos mies ei koskaan koe seksuaalista vetoa ketään naista kohtaan ei käytännössä ole mitään perustetta pitää häntä heterona.

64) Jos se on kaikkee, se on kyllä Michael Jackson, ny mä hiffasin! nämä muut setalaiset on siis heteroita mutta jotenki muuten poikkeavia, kuten eläimiin sekoilija, pervot, petofilit... jne. ${ }^{8}$

\section{Henkilö- ja minädiskurssi}

Toisin kuin homoaineistossa, heteroaineistossa on vain vähän viittauksia yksittäisiin tunnettuihin henkilöihin ja heidän seksuaalisuuteensa tai mielipiteisiinsä tai henkilöryhmiin. Sen sijaan merkille pantavaa on viittaaminen omaan itseen eli viestin kirjoittajaan. Tämä näkyy yhtäältä pronominien minä ja itse runsaana käyttönä, mutta myös sellaisten verbimuotojen käyttönä, jossa on näkyvillä ensimmäinen persoona, tavallisimmin olla ja $e i$-verbien muodot, kuten olen(-ko, -kin), olevani, oon ja en, enkä. Näiden ilmausten päätyminen avainsanojen listalle on sikäli harvinaista, että ne ovat kielen yleisintä sanastoa eivätkä ne yleensä ole tyypillisiä tekstimassoja kuvaavia ja erottelevia ilmauksia. Niiden läsnäolo hetero-avainsanojen joukossa kieliikin usein identiteetin pohdinnasta (65-67): keskustelijat representoivat omaa seksuaalisuuttaan ja kielentävät omia ajatuksiaan, pohdintojaan ja kokemuksiaan ja antavat siten omakohtaisen näkökulman seksuaalisuuden pohdinnalle. Osittain tämä selittyy myös sillä, että edellä kuvattuihin mentaalisiin verbeihin (kognitioja tunneverbit) liittyy yleensä juuri elollinen ja tajunnallinen tekijä (ks. VISK $₫ 445$ ), ja tässä aineistossa se on usein juuri itse tai minä.

65) Itselläni ei ole mitään homoseksuaaleja vastaan, mutta koska itse olen hetero, on erään ystäväni käytös alkanut hieman ahdistaa.

66) Itse olen täysi hetero, en tunne mitään

8 Rikoslain piiriin kuuluvia seksuaalikäyttäytymisen muotoja, kuten pedofiliaa (myös pedofiili) ei ollut 500 avainsanan listalla, vaikka usein ajatellaankin, että tällainen käyttäytyminen liitetään homoseksuaalisuuteen (ks. esim. Herek 2002; Opetusministeriö 2016, 88-89). 
seksuaalista vetoa samaan sukupuoleen, mutta mitä sitten vaikka tuntisinkin?

67) Kai minä hetero olen, koska miehiin kuitenkin tunnen vetoa ja ihastumista.

68) Enkä minä syrji Halosen sukupuolinäkemyksiä, mutta presidentiksi haluan silti ihan normaalin heteron, en entistä Setan puheenjohtajaa.

\section{Sukupuolidiskurssi}

Kun aineistoa tarkastelee vielä sukupuolimerkityskenttään kuuluvien avainsanojen valossa, paljastuu, että toisin kuin homokeskusteluissa, heteroaineistossa puhutaan runsaasti miehistä ja naisista sekä sukupuolesta ylipäätään (ks. myös edellä esimerkit 52, 63, 67): aineiston avainsanoissa on runsaasti sanojen mies ja nainen taivutusmuotoja samoin kuin sukupuoli-sanan muotoja. Yleisiä ovat rinnastukset mies ja/tai nainen (69-71) sekä mieben tai naisen kanssa olemisen tai elämisen käsittely $(72,73)$ ja oman heteroseksuaaliidentiteetin esiintuominen $(74,75)$. Kun mies ja nainen rinnastetaan, keskustelun kohteet ovat moninaiset: $\mathrm{mm}$. heterosuhteen luonnollisuus homosuhteeseen verrattuna (69), eri sukupuolta olevien ystävyys (70) tai vaikkapa yhteiskunnallinen asema (71), eivätkä naisen ja miehen kanssa olemisen käsittelyt toki rajoitu pelkästään seksiin (73). Tällekin diskurssille on jokseenkin tyypillistä identiteetteihin ja ihmissuhteisiin liittyvä pohdinta ja itserepresentointi sekä omakohtaisten kokemusten esiintuonti.

69) Joo menkööt homot omalle saarekkeeleen ja laatikoot siellä omat homolait. Heterot haluaa olla omalla luonnollisellaan maallaan siis mies ja nainen vain voi olla avioliitossa.

70) Muutenkin kyllä mies ja nainen voivat olla ystäviä platoonisella tasolla vaikka ovat heteroja molemmat.
71) Jos mies ja nainen asuvat yhdessä, mutta eivät ole edes heteroita, ovatko he siis avopari automaattisesti?

72) Kannattaisi olla vaan vaikka väkisin heterona, koska hennon naisen kanssa mies pärjää vaikka olisi huijari mutta miehen kanssa voi mennä henki...

73) Minä olen kyllä liian betero asuakseni kahdestaan miehen kanssa ja hoitajat yrittivät joskus toimittaa minua takaisin mielisairaalaan.

74) Minä olen hetero mies ja on todella vaikeaa löytää heteroita naisia.

75 -- mutta näi heterona naisena tieteski ite tykkään et hetero mies olis pop... =o)

\section{POHDINTA}

Artikkelissa tarkasteltiin Suomi24-keskustelupalstan homouteen ja heterouteen liittyviä toistuvia diskursseja korpusavusteisen diskurssintutkimuksen menetelmin; lähtökohtana analyysissa oli tilastollinen avainsanaanalyysi. Koska verkkokeskusteluille on yleensä tyypillistä rosoisuus eli hyvin monenlaisten kannanottojen ja mielipiteiden kirjavuus (ks. esim. Matikainen 2011), tässä työssä on keskitytty tilastollisen lähestymistavan avulla nimenomaan taajaan esiintyviin ja toistuviin diskursseihin, mikä jättää luonnollisesti osan diskursseista tutkimuksen ulkopuolelle; näiden tarkasteleminen on tärkeää toisessa yhteydessä. Yhtäältä tutkimus paljastaa, että valtakunnallisessakin mediassa tavallinen uskonnollinen tematiikka toistuu myös koko kansan keskustelupalstoilla homoista puhuttaessa. Tähän voi osasyynä olla juuri keskusteluohjelmissa käyty uskonnollisväritteinen debatointi. Vaalit ja laajemminkin poliittiset tapahtumat nostavat puolestaan poliittisen keskustelun mukaan homoista puhumisen yhteyteen, tämä näkyy esimerkiksi puolueista ja poliitikoista puhumisena. Jossain määrin oireellista on, että huolimatta keskustelupals- 
tojen moderoinnista niillä elää ja voi hyvin myös voimakas väkivalta- ja vihadiskurssi, eivätkä siitä osattomaksi jää myöskään seksuaalivähemmistöt.

Koska kieli ei ole koskaan yksilön itsensä oma asia eivätkä käsityksetkään omia, sillä diskurssit rakentuvat ympäristössä sosiaalisesti ja muovautuvat toistuessaan diskurssiparadigmaksi, josta syntyy helposti yleinen totuus, olisi keskusteluun osallistujien (ja moderaattorien) kannettava vastuu omasta viestinnästään ja sen vaikutuksista. Viestien kirjoittajat eivät välttämättä tule ajatelleeksi, että viestit voivat saavuttaa laajankin joukon lukijoita, kun viestejä kopioidaan (lähes) sellaisinaan omien viestien osaksi. Verkkokeskustelut toimivatkin kulttuuristen diskurssien alustana, josta ne helposti leviävät laajalle (ks. Hakala \& Vesa, 2015, s. 201). Niinpä esimerkiksi yksittäisten ihmisten henkilöyteen liittyvä keskustelu on ongelmallista, vaikka kohteet ovatkin yleensä julkisuuden henkilöitä.

Heteroaineiston valossa seksuaalisuuden maailma näyttäytyy vallan toisenlaiselta: ääneen pääsevät erityisesti ajattelua, pohdintaa, tunteita ja sukupuolisuutta koskevat kannanotot. Diskurssit ovat toisiinsa kietoutuneita ja niitä voi toisinaan olla vaikea (jos on tarpeenkaan) erottaa toisistaan. Tässä tutkimuksessa ne olisi mahdollista teemoittaa yhdeksikin diskurssiksi, jolloin voisi jopa väittää, että heteroutta rakennetaan keskustelupalstoilla seksuaalisuutta ja sukupuolen merkitystä koskevan mentaalisen diskurssin, usein myös itserepresentaation avulla. Havaittujen merkitysryhmien niputtaminen yläteeman alle piilottaisi kuitenkin sen, millä tavalla seksuaalisuudesta heterouden yhteydessä puhutaan: yhtäältä kognition tasolla, yhtäällä tunteen tasolla. Siksi on perusteltua pitää diskurssit erillään. Vastaavaa diskurssia (tai vastaavia diskursseja) tapaa toki myös homouden käsittelyn yhteydestä, mutta sitä (niitä) ei toisteta läheskään yhtä taajaan. Seksuaalivähemmis- töjen maailma keskustelupalstoilla merkityksellistyy siis vallan erilaiseksi kuin heteromaailma. Aiemmissa tutkimuksissa (mm. Juvonen, 2002) esiin tullut pedofilia- tai lainvastaisten tekojen diskurssi ei kuitenkaan näyttäydy keskustelupalstoilla voimakkaana nimenomaan korpusavusteisen menetelmän ja merkitsevimpien avainsanojen näkökulmasta. Silti ei voi väittää, etteikö stereotyyppinen rangaistavuuteen ja patologisuuteen keskittynyt monikymmenvuotinen diskurssi homoseksuaalisuudesta edelleen värittäisi keskustelua. Myöskään Cooperin (2004) havaitsema seksuaaliseen aktiin ja homouden seksualisointiin keskittyvä keskustelu ei nouse tilastollisten avainsanojen valossa merkittäväksi aineistoa kokonaisuutena tarkasteltaessa, vaikka tämäkään aihe ei ole tyystin jäänyt keskusteluteemoista pois.

Verkkokeskustelujen tarkastelu tarjoaa väylän päästä kiinni yhteiskunnassa vallitseviin ajankohtaisiin teemoihin (Lagus ym., 2016, s. 40-42), asenteisiin ja arvoihin. On kuitenkin pidettävä mielessä, että verkkokeskusteluihin osallistujat muodostavat vain osan kansakunnan äänestä, sillä vain pieni joukko suomalaisista osallistuu aktiivisesti verkkokeskusteluihin (Hakala \& Vesa, 2005, s. 207; Matikainen, 2009, s. 33). Hakala ja Vesa (mp.) korostavatkin, että verkkokeskusteluista havaittujen käsitysten ja asenteiden edustavuutta on syytä tarkastella kriittisesti; käsillä olevassa tutkimuksessa tilastollinen korpusanalyysi ja erittäin laaja tutkimusaineisto parantavat tulosten luotettavuutta verrattuna pienillä aineistoilla tehtyyn kvalitatiiviseen tutkimukseen, mutta toisaalta nostavat esiin etupäässä tyypillisyyksiä ja toistuvuutta ja jättävät huomiotta mahdollisen laadullisen kirjon. Tulokset osittain vahvistavat aiempia havaintoja seksuaalisvähemmistöihin liittyvistä diskursseista ja heteroseksuaalisuuden normitetusta asemasta mutta tuovat esiin myös uusia näkökulmia - etenkin heteroista 
ja heteroseksuaalisuudesta puhumiseen. Toisessa yhteydessä on tarpeen yhtäältä tarkentaa myös muiden hakusanojen (kuten homoseksuaali, hintti, hetsku) avulla tässä artikkelissa esitettyjä diskursseja ja toisaalta myös syventää tilastollisin perustein löydettyjä diskursseja valottamalla niitä laadullisen analyysin keinoin.

\section{KIRJALLISUUS}

Anderson, E. (2011a). Masculinities and sexualities in sport and physical cultures: Three decades of evolving research. Journal of Homosexuality, 58, 565-578.

Anderson, E. (2011b). The rise and fall of western homohysteria. Journal of Feminist Scholarship, 1, 80-94. Haettu 21.11.2017 osoitteesta http://www.jfsonline.org/issue1/pdfs/AndersonFINAL.pdf

Anthony, L. (2015). AntConc. Version 3.4.4. Computer Software. Tokyo: Waseda University. Haettu 12.3.2017 osoitteesta http://www.laurenceanthony.net/

Armstrong, J. (1997). Homophobic slang as coercive discourse. Teoksessa A. Livia \& K. Hall (toim.), Queerly phrased. Language, gender, and sexuality, (s. 335-345). Oxford: OUP.

Bachmann, I. (2011). Civil partnership - "gay marriage in all but name": A corpus-driven analysis of discourses of same-sex relationships in the UK parliament. Corpora, 6, 77-105.

Baker, P. (2006). Using corpora in discourse analysis. London: Continuum.

Baker, P. (2005). Public discourses of gay men. London: Routledge.

Baker, P. (2004a). 'Unnatural acts': Discourses of homosexuality within the House of Lords debates on gay male law reform. Journal of Sociolinguistics, 8, 88-106.

Baker, P. (2004b). Querying keywords. Questions of difference, frequency, and sense in keywords analysis. Journal of English Linguistics, 32, 346-359.

Baker, P., Gabrielatos, C., KhosraviNik, M., Krzyzanowski, M., McEnery, T. \& Wodak, R. (2008). A useful methodological synergy? Combining critical discourse analysis and corpus linguistics to examine discourses of refugees and asylum seekers in the UK press. Discourse \&
Society, 19, 273-306

Barker, C. (2003). Cultural studies: Theory and practice. London: Sage.

Beißwenger, M., Oostdijk, N., Storrer, A. \& van den Heuvel, H. (toim.) (2014). Building and annotating corpora of computer-mediated communication: Issues and challenges at the interface of corpus and computational linguistics. Special Issue, Journal for Language Technology and Computational Linguistics 29(2).

Beißwenger, M. \& Storrer, A. (2008). Corpora of computer-mediated communication. Teoksessa A. Lüdeling \& M. Kytö (toim.), Corpus linguistics. An international handbook, (s. 292-308). Berlin: Mouton de Gruyter.

Bondi, M. \& Scott, M. (toim.) (2010). Keyness in texts. SCL 41. Amsterdam: John Benjamins.

Cameron, D. (2001). Working with spoken discourse. London: Sage.

Cameron, D. \& Kulick, D. (2006). Heteronorms. Teoksessa D. Cameron \& D. Kulick (toim.), The language and sexuality reader, (s. 165-168). London: Routledge.

Charpentier, S. (2001). Pyhä, sukupuoli ja heteronormatiivisuus. Sukupuolten pyhä järjestys lesbo- ja homoliittokeskustelussa. Naistutkimus - Kvinnoforskning, 14(1), 4-15.

Charpentier, S. (2000). Gender, body and the sacred. Heterosexual hegemony as a sacred order. Queen - Journal of Rhetorics and Power, 1(1). Haettu 14.5.2017 osoitteesta http://www.arsrhetorica.net/Queen/Volume11/QueenVolume.html

Coates, J. (2013). The discursive production of everyday heterosexualties. Discourse \& Society, 24, 536-552.

Cooper, C.A. (2004). Cyber-hate and the disinhibiting effects of anti-gay speech on the Internet. Teoksessa R.A. Linn (toim.), Race, gender, media. Considering diversity across audiences, content and producers (s. 258-265). Boston: Pearson Education.

Edelstein, Y. \& Wolf, C. (2013). Report and recommendations of the task force on Internet hate of the inter-parliamentary coalitions for combating anti-semitism (ICCA). Haettu 9.4.2017 osoitteesta http://www.adl.org/assets/pdf/presscenter/ICCA-Report.pdf

Faulkner, E. (2006). Homophobic hate propaganda in Canada. Journal of Hate Studies, 5, 63-97. 
Giles, D., Stommel, W., Paulus, T., Lester, J. \& Reed, D. (2015). Microanalysis of online data: The methodological development of "Digital CA". Discourse, Context \& Media, 7, 45-51.

Granger, S. \& Meunier, F. (toim.) (2008). Phraseology. An interdisciplinary perspective. Amsterdam: John Benjamins.

Hajek, C. \& Giles, H. (2005). Intergroup communication schemas: Cognitive representations of talk with gay men. Language and Communication, 25(2), 161-181.

Hakala, S. \& Vesa, J. (2015). Verkkokeskustelut ja sisällön erittely. Teoksessa S.-M. Laaksonen, J. Matikainen \& M. Tikka (toim.), Otteita verkosta: Verkon ja sosiaalisen median tutkimusmenetelmät. Verkkojulkaisu. Tampere: Vastapaino. Haettu 15.5.2017 osoitteesta https://www-ellibslibrary-com.ezproxy.jyu.fi// book/9789517684101

Herek, G.M. (2002). Gender gaps in public opinion about lesbians and gay men. Public Opinion Quarterly, 66, 40-66.

Herz, M. \& Johansson, T. (2015). The normativity of the concept of heteronormativity. Journal of Homosexuality, 62, 1009-1020.

Hunston, S. (2001). Colligation, lexis, pattern, and text. Teoksessa M. Scott \& G. Thompson (toim.), Patterns of text. In honour of Michael Hoey (s. 13-33). Amsterdam: John Benjamins. Jantunen, J.H. (2009). Minulla on aivan paljon rahaa. Fraseologiset yksiköt suomen kielen opetuksessa. Virittäjä, 113, 356-381. Haettu 15.5.2017 osoitteesta http://ojs.tsv.fi/index. php/virittaja/article/view/4202

Jantunen, J.H. (2012). Akateemiset ja populaaritekstit korpusvertailussa: Sanalistat, avainsanat ja fraseologiset yksiköt. Teoksessa V. Heikkinen, E. Voutilainen, P. Lauerma, M. Lounela \& U. Tiililä (toim.), Genreanalyysi - tekstilajitutkimuksen käytäntöä, (s. 186-213). Helsinki: Kotimaisten kielten keskus. Haettu 15.5.2017 http://kaino.kotus.fi/www/verkkojulkaisut/ julk29/Genreanalyysi.pdf

Jantunen, J.H. (2017). Lexical and morphological priming. A holistic phraseological analysis of the Finnish time expression kello. Teoksessa M. Pace-Sigge \& K.J. Patterson (toim.), Lexical priming: Applications and advances, (s. 254272). Amsterdam: John Benjamins.

Juvonen, T. (2015). Kaapista kaapin päälle. Tam- pere: Vastapaino.

Juvonen, T. (2004). Nyt se näkyy, nyt taas ei: Heteronormatiivisuus ja homoseksuaalisuuden esillepano Helsingin Sanomissa. Tiedotustutkimus, 27(2), 34-55.

Juvonen, T. (2002). Varjoelämää ja julkisia salaisuuksia. Homoseksuaalisuuden rakentuminen sotienjälkeisessä Suomessa. Tampere: Vastapaino.

Kaplan, A.M. \& Haenlein, M. (2010). Users of the world, unite! The challenges and opportunities of social media. Business Horizons, 53, 59-68.

Katila, J. (2011). Vuosien 1996 ja 2010 homoillat suurennuslasin alla. Queer-teorian inspiroima diskurssianalyyttinen tutkimus sukupuolen, seksuaalisuuden ja perheen rakentumisesta ajankobtaisohjelmissa. Sosiaalipsykologian pro gradu -tutkielma, Tampereen yliopisto.

Laaksonen, S.-M. \& Matikainen, J. (2015). Tutkimuskohteena vuorovaikutus ja keskustelu verkossa. Teoksessa S.-M. Laaksonen, J. Matikainen \& M. Tikka (toim.), Otteita verkosta: Verkon ja sosiaalisen median tutkimusmenetelmät. Verkkojulkaisu. Tampere: Vastapaino. Haettu 12.4.2017 osoitteesta https://www-ellibslibrary-com.ezproxy.jyu.fi//book/9789517684101

Lagus, K., Pantzar, M., Ruckenstein, M. \& Ylisiurua, M. (2016). Suomi24. Muodonantoa aineistolle. Helsingin yliopiston valtiotieteellisen tiedekunnan kuluttajatutkimuskeskuksen julkaisuja 10. Helsinki: Helsingin yliopisto. Haettu 27.1.2017 osoitteesta http://blogs.helsinki.fi/ citizenmindscapes/files/2016/05/257383_ HY_VALT_suomi24_muodonantoa_aineistolle.pdf

Lehtonen, J. (2003). Seksuaalisuus ja sukupuoli koulussa. Näkökulmana heteronormatiivisuus ja ei-heteroseksuaalisten nuorten kertomukset. Helsinki: Yliopistopaino.

Marshall, P.D. (2006). New media - new self: The changing power of celebrity. Teoksessa P.D Marshall (toim.) The celebrity culture reader, (s. 634-644). New York: Routledge.

Matikainen, J. (2011) Verkkokeskustelua homoillasta - osallistumisen kulttuuria? Media \& Viestintä, 34(1), 92-98.

Matikainen, J. (2009). Sosiaalisen ja perinteisen median rajalla. Viestinnän laitoksen tutkimusraportteja 3/2009. Helsingin yliopisto: Viestinnän tutkimuskeskus CRC. Haettu 15.5.2017 osoitteesta http://www.helsinki.fi/crc/Julkai- 
sut/sosiaalisen_ja_perinteisen_median_rajalla_raportti.pdf

Mautner, G. (2009). Checks and balances: How corpus linguistics can contribute to CDA. Teoksessa R. Wodak \& M. Meyer (toim.), Methods of critical discourse analysis, (s. 122-143). Los Angeles: Sage.

Meta-Share. (2016). The Suomi24 Corpus. Haettu 28.1.2017 osoitteesta http://metashare.csc. fi/repository/browse/the-suomi-24-corpus/ b4db73da85ce11e4912c005056be118ea699d93902fa49d69b0f4d1e692dd5fl/

Meyer, D. (2012). An intersectional analysis of lesbian, gay, bisexual, and transgender (LGBT) people's evaluations of anti-queer violence. Gender \& Society, 26, 849-873.

Meyers, E.A. (2010). Gossip talk and online community: Celebrity gossip blogs and their audiences. Dissertations 292. University of Massachusetts. Haettu 13.5.2017 osoitteesta http:// scholarworks.umass.edu/open_access_dissertations/292

Milani, T.M. (2013). Are 'queers' really 'queer'? Language, identity and same-sex desire in a South African online community. Discourse \& Society, 24, 615-633.

Morrish, E. (1997). "Falling short of God's ideal": Public discourse about lesbians and gays. Teoksessa A. Livia \& K. Hall (toim.), Queerly phrased. Language, gender, and sexuality, (s. 335-345). Oxford: OUP.

Opetusministeriö (2016). "Usein joutuu miettimään, miten pitäisi olla ja minne olla menemättä. Selvitys vihapubeesta ja häirinnästä ja niiden vaikutuksista eri vähemmistöryhmiin. Selvityksiä ja ohjeita 7/2016. Helsinki: Opetusministeriö. Haettu 1.3.2017 osoitteesta http://oikeusministerio.fi/julkaisu?pubid=UR $\mathrm{N}: I S B N: 978-952-259-496-9$

Pajunen, A. (2001). Argumenttirakenne. Asiaintilojen luokitus ja verbien käyttäytyminen suomen kielessä. Helsinki: Suomalaisen Kirjallisuuden Seura.

Partington, A., Duguid, A. \& Taylor, C. (2013). Patterns and meanings in discourse: Theory and practice in corpus-assisted discourse studies (CADS). Studies in Corpus Linguistics 55. Amsterdam: John Benjamins.
Pascoe, C. J. (2005). 'Dude, you're a fag': Adolescent masculinity and the fag discourse. Sexualities, 8, 329-346.

Pietikäinen, S. \& Mäntynen, A. (2009). Kurssi kohti diskurssia. Tampere: Vastapaino.

Platt, L. \& Lenzen, A. (2013). Sexual orientation microaggressions and the experience of sexual minorities. Journal of Homosexuality, 60, 10111034.

Pöyhtäri, R., Haar, P. \& Raittila, P. (2013). Vihapuhe sanavapautta kaventamassa. Tampere: TUP.

Ruckenstein, M. (2017). Suomi24-käyttäjäkyselyn tuloksia. Citizen Mindscapes hankkeen verkkosivusto. Haettu 21.11.2017 osoitteesta http://blogs.helsinki.fi/citizenmindscapes/2017/08/21/suomi24-kayttajakyselyntuloksia/

Scott, M. \& Tribble, C. (2006). Textual patterns: Key words and corpus analysis in language education. SCL 22. Amsterdam: John Benjamins.

Soininen, P. (2015). Seksuaali- ja sukupuolivähemmistöibin kohdistettu vihapube internetissä. Sukupuolentutkimuksen pro gradu -tutkielma, Tampereen yliopisto. Haettu 3.4.2017 osoitteesta https://tampub.uta.fi/bitstream/ handle/10024/97752/GRADU-1436774527. pdf ? sequence $=1$

Stubbs, M. (1997). Whorf's children: Critical comments on critical discourse analysis. Teoksessa A. Ryan \& A. Wray (toim.), Evolving models of language, (s. 100-116). Clevedon: Multilingual Matters.

Sunderland, J. (2004). Gendered discourses. Houndmills: Palgrave Macmillan.

Suomi24 (2017). Suomi24 Keskustelun objeet. Haettu 28.1.2017 osoitteesta http://www.suomi24.fi/opastus/keskustelu

VISK (2004). A. Hakulinen, M. Vilkuna, R. Korhonen, V. Koivisto, T.R. Heinonen, \& I. Alho (toim.), Iso suomen kielioppi. Helsinki: Suomalaisen Kirjallisuuden Seura. Verkkoversio. Haettu 11.4.2017 osoitteesta http://scripta.kotus.fi/ visk URN:ISBN:978-952-5446-35-7

Tolvanen, J. (2007). Kotileikkejä ja lastenkasvatuspuubia. Kevä̈n 1996 homoliittokeskustelu Suomen sanomalehdistössä. Sosiologian pro gradu -tutkielma, Jyväskylän yliopisto. 


\section{GAYS AND STRAIGHTS IN SUOMI24: ANALYSIS OF DIGITAL DISCOURSES}

Jarmo Harri Jantunen, Department of Languages and Communication, University of Jyväskylä

The article focuses on recurring discourses related to homosexuality and heterosexuality on the Suomi 24 discussion forum. The analysis was implemented through corpus-assisted discourse study (CADS), in which statistical keyword analysis based on big data highlights (certain) socially divided discourses on the discussion forum. On the one hand, the results support earlier observations made in media analyses on strong affects and hate speech as well as on the tendency to politicise and religionise homosexuality. On the other hand, the study also reveals the personification of homosexual discourses or their links to specific places and groups of people. Furthermore, heterosexual discourses clearly differ from homosexual discourses: typical of the former is both a rational and an emotionally determined discussion on sexual orientation, sexuality and gender, as well as the selfrepresentation of one's own desires and sexuality.

Keywords: discourse, discussion forum, heterosexuality, homosexuality, phraseology, social media 